\title{
Effects of Glyphosate and Polyoxyethylene Amine on Metabolic Rate and Energy Reserves of Procambarus clarkii Juveniles
}

\author{
J.L. Frontera ${ }^{1}$, Nicole Gilette ${ }^{2}$, Breanna Hull ${ }^{2}$, Jacquie Korang ${ }^{2}$, Carolina Amorim ${ }^{2}$, I. Vatnick ${ }^{2}$ and \\ E.M. Rodríguez ${ }^{*}, 1$
}

${ }^{I} I B B E A$ - Department of Biodiversity and Experimental Biology, FCEyN, University of Buenos Aires, C1428EHA Buenos Aires, Argentina

${ }^{2}$ Department of Biology, Widener University, Chester, PA 19809, USA

\begin{abstract}
P. clarkii juvenile crayfish were exposed during 60 days to sublethal concentrations of glyphosate (G), polyoxyehtylene amine $(\mathrm{P})$ or a combination of both $(\mathrm{G}+\mathrm{P})$, together with a control group of aged tap water $(\mathrm{C})$. At the end of the experiment, the following statistical differences were noted, with respect to control: 1) a lower metabolic rate in both $\mathrm{G}$ and $\mathrm{G}+\mathrm{P}$ groups, 2) a higher glycemia in $\mathrm{G}$ group with no differences in hemolymphatic lactate levels, 3) a lower muscle glycogen levels in both $\mathrm{P}$ and $\mathrm{G}+\mathrm{P}$ groups, 4) a lower level of protein muscle in the $\mathrm{P}$ group. Taken together, these results suggest that glyphosate may cause a metabolic arrest. Additionally, under chronic exposure conditions, polyoxyehtylene amine acts as a strong stressor, leading to the utilization of both muscle carbohydrate and protein reserves.
\end{abstract}

Keywords: Crayfish, energy reserves, glyphosate, metabolic rate, POEA.

\section{INTRODUCTION}

Glyphosate [N-(phosphonomethyl) glycine] is a nonselective systemic herbicide that inhibits the growth of aquatic and terrestrial plants by acting as a competitive inhibitor of the enzyme 5-enolpyruvylshikimate-3-phosphate synthase, involved in the synthesis pathway of aromatic amino acids present in plants and microorganisms, but not in animals [1,2]. Since its introduction in the late 1970s, glyphosate has been one of the pesticides with the highest rate of increase in their production and use [3,4]. Roundup (Monsanto, Creve Coeur, Missouri) is one of the main commercial formulations of glyphosate, also containing POEA (polyoxyethylene amine) as a surfactant aimed at increasing the absorption of glyphosate. The half-life of glyphosate ranges from 7 to 70 days, whereas that of POEA ranges from 21 to 28 days, depending on environmental conditions [3]. Environmental water concentrations of glyphosate in the United States have reached values near 3 $\mathrm{mg}$ acid equivalents (a.e.)/L $[3,5]$ and up to $7.6 \mathrm{mg}$ a.e./L have been reported in Australia [6].

Although a low acute toxicity of glyphosate has been reported [7], recent studies indicate that continuous exposure to glyphosate could adversely affect both terrestrial and aquatic habitats, as well as non-target organisms such as amphibians [8,9]. Recently it has been suggested that glyphosate based herbicides, especially those which use tallowamine surfactants, may be linked to global amphibian

*Address correspondence to this author at the IBBEA - Department of Biodiversity and Experimental Biology, FCEyN, University of Buenos Aires. C1428EHA Buenos Aires, Argentina; Tel: +54-11-45763300,

Ext. 210; Fax: +54-11-54763384; E-mail: enrique@bg.fcen.uba.ar decline due to their increase use in the agrarian industry [10]. Exposure to sublethal concentrations of glyphosate caused ultrastructural damage in the liver of the fish C. capio [11]. Alterations in liver, kidney, and gills of Nile tilapia after exposure to acute and chronic sublethal concentrations of Roundup have been also reported [12], as well as alterations of several enzymatic and metabolic pathways in several fish species [13]. In crustaceans, Roundup ${ }^{\mathbb{B}}$ caused a reduction in shrimp growth [14]. Besides, advanced juveniles of the crayfish C. quadricarinatus exposed for $50 \mathrm{~d}$ to a mixture of glyphosate and POEA, showed a significant reduction in both growth rate and muscle protein level, among other changes in carbohydrate and lipid reserves [15].

The red swamp crayfish, Procambarus clarkii is a widespread species inhabiting the south of the USA territory, being particularly conspicuous in the Mississippi Delta, where the herbicide glyphosate is extensively used $[16,17]$. The Mississippi Delta encompasses about $65 \%$ of all agricultural areas in the US and has been monitored since 1995 to assess the impact of agricultural herbicides and pesticides on water quality [18]. Furthermore, glyphosate has been detected in rainwater and in the air in the Mississippi Delta [17].

P. clarkii has been used as model crustacean species for a wide array of biological studies, including the evaluation of pollutant toxicity by means of toxicological bioassays $[19,20]$. The objective of the current study was to test the effects of a sublethal concentration of pure glyphosate (acid form), alone and in combination with POEA, on growth, metabolic rate, and energy reserve levels (carbohydrate and proteins) of juvenile freshwater crayfish P. clarkii. 


\section{METHODOLOGY}

Crayfish were purchase from a local dealer (Carolina Supply Co.). Sixty four juveniles weighing $3.44 \pm 0.18 \mathrm{~g}$ were used. The experiment lasted for 60 days, beginning on mid February. Sixteen juveniles were assigned to each of the following experimental groups:

C (control): water without addition of chemicals.

G: glyphosate at a concentration of $22.5 \mathrm{mg} / \mathrm{L}$.

P: POEA (polyoxyethylene amine) at a concentration of 7.5 $\mathrm{mg} / \mathrm{L}$.

G+P: a mixture of $30 \mathrm{mg} / \mathrm{L}(7.5 \mathrm{mg} / \mathrm{L}$ of POEA and $22.5 \mathrm{mg}$ of glyphosate).

All stock solutions of glyphosate and POEA (Sigma Co., Missouri, USA, 99.8\% purity) were prepared weekly by dissolving the appropriate amount of the chemicals in distilled water. All test solutions were prepared following the standard procedures recommended by the American Public Health Association et al. [21]. Concentration of both glyphosate and POEA were chosen according to previous studies on juvenile crayfish Cherax quadricariatus [16]. Each juvenile was isolated in a plastic recipient filled with $400 \mathrm{~mL}$ of dilution freshwater (pH: 7.6, hardness: $70 \mathrm{mg} / \mathrm{L}$ as $\mathrm{CaCO}_{3}$ equivalents), under continuous aeration. Animals were maintained at room temperature $\left(22^{\circ} \mathrm{C}\right)$ and 14:10 L:D cycle. The animals were fed three times a week, ad libitum, with Tetra Pond ${ }^{\circledR}$ and fresh leaves of Elodea sp. After each feeding, water of all recipients was replaced.

Weight gain (WG) was determined using the weight on day 1 and day 60 of the study, according to the following equation: $\mathrm{WG}=(\mathrm{FW}-\mathrm{IW}) / \mathrm{IW} * 100$, where $\mathrm{IW}=$ initial weight and $\mathrm{FW}=$ final weight of juveniles. All containers were daily examined for molts; molted casts was kept for $48 \mathrm{~h}$ in the container (because recently molted animals often eat them), finally discarding the uneaten rests.

At day 60, oxygen consumption of each animal was measured in a flow-through respirometer system, consisting of a $4.5 \mathrm{~cm}$ diameter x $12 \mathrm{~cm}$ high cylindrical, double walled glass metabolic chamber (Labglass, Vineland, NJ) and oxygen consumption was monitored with a galvanic oxygen probe and D201 controller (Qubit Systems) and analyzed using Loligo Autoresp LDAQ software (Loligo Systems) The sealed metabolic chamber was immersed in a glass aquarium containing $4 \mathrm{~L}$ of aerated aged tap water at $22{ }^{\circ} \mathrm{C}$, and was connected to a pump for a continuous flow-through of water in a closed system. Each animal was initially weighed, placed in the chamber and left $10 \mathrm{~min}$ for acclimation; the oxygen content was then recorded for 20 min, to estimate the oxygen consumption rate as $\mu \mathrm{g}$ $\mathrm{O}_{2} / \mathrm{min} / \mathrm{g}$. Animals were not fed during the $48 \mathrm{~h}$ previous to each recording, in order to avoid the specific dynamic action.

At the end of the experiment, a small sample of hemolymph $(<200 \mu \mathrm{L})$ was taken from the base of the appendages of each animal, using a $29 \mathrm{G}$ needle and a tuberculin syringe, to be finally stored in an Eppendorf tube at $-70^{\circ} \mathrm{C}$. Then, all animals were sacrificed and the abdominal muscle was dissected and stored at $-70{ }^{\circ} \mathrm{C}$ for subsequent analysis. Glucose was measured in hemolymph samples by a glucose oxidase and peroxidase assay (Cayman
Chemical). Lactate was analyzed by means of a 96-well Fluorescent kit (Cayman Chemical), which produces the oxidation of D-lactate to pyruvate, along with the concomitant reduction of $\mathrm{NAD}^{+}$to $\mathrm{NADH}$, which finally reacts with the fluorescent substrate to yield a highly fluorescent product.

Glycogen was extracted from muscle by the method of Van Handel [22] and quantified as glucose as indicated above, after performing acid hydrolysis with $\mathrm{HCl}$ and subsequent neutralization with $\mathrm{Na}_{2} \mathrm{CO}_{3}$. Protein extraction was performed by the addition of $30 \% \mathrm{KOH}$ to each sample, followed by $2 \mathrm{~h}$ incubation at $100{ }^{\circ} \mathrm{C}$. Muscle protein level was assessed according to Lowry et al. [23] using bovine albumin as a standard and measuring absorbance at $650 \mathrm{~nm}$.

For each variable, a one-way ANOVA, followed by multiple comparisons LSD test [24] were used. Data normality and homogeneity of variances were always confirmed. A 5\% confidence level was considered in all cases.

\section{RESULTS AND DISCUSSION}

Although actual concentrations were not measured, in a previous study where a similar experimental setup was employed [15], a high correlation between nominal and measured concentration was verified in 24-h aged samples having the same glyphosate concentration used in the current study. Regarding environmental concentrations, presence of glyphosate in agriculture areas of Mississippi Delta has been also reported at high concentrations in both surface and rain water, as a consequence of the exponential increment in the use of glyphosate during the last two decades (more than 8 times in United States, between 1994 and 2007) [16].

Both mortality and molting percentages are shown in Table 1. Although $\mathrm{G}+\mathrm{P}$ was the group that showed the highest mortality (50\%) and lower molting percentage $(12.5 \%)$, no significant differences $(p>0.05)$ were seen with respect to control, in any case. Although a $68 \%$ of molting was seen in the P group, no significant differences $(p>0.05)$ were neither found as compared to control. Concerning growing, the $\mathrm{G}$ and $\mathrm{G}+\mathrm{P}$ groups had the lowest weight gain at the end of the experiment, but they were not statistically different $(\mathrm{p}>0.05)$ with respect to control (Table 1).

No significant $(\mathrm{p}>0.05)$ differences among groups were noted in oxygen consumption rate at the beginning of the experiment. However, at the end of the experiment, glyphosate, either alone or in combination with POEA, significantly decreased the oxygen consumption rate of $P$. clarkii juveniles (Fig. 1). Besides, the $G$ group showed a blood glucose level significantly $(p<0.05)$ higher than control (C), while $\mathrm{G}+\mathrm{P}$ had an intermediate value between $\mathrm{C}$ and $G$ groups (Fig. 2). No significant $(p>0.05)$ differences in hemolymphatic lactate levels were observed among groups (Fig. 2). Taken together, these results suggest that glyphosate could be exerting a metabolic arrest, decreasing aerobic metabolism (and presumably glucose consumption), while no increment in the anaerobic metabolism was evident. We observed in juveniles of the crayfish Cherax quadricarinatus [15], a lower oxygen consumption rate during chronic exposure to the same concentration of glyphosate used in the current study, but in that previous study anaerobic metabolism was not determined. In this sense, the current 
Table 1. Mortality, molting and weight gain at the end of the experiment, for each experimental group.

\begin{tabular}{|c|c|c|c|c|}
\hline Experimental Group & Percentage of Mortality & Percentage of Molting & Weight Gain & Final N \\
\hline \hline Control & 28.6 & 37.5 & $86.04 \pm 26.87$ & 10 \\
\hline Glyphosate & 14.3 & 50.0 & $62.79 \pm 8.71$ & 12 \\
\hline POEA & 14.3 & 68.75 & $88.69 \pm 14.50$ & 12 \\
\hline Glyphosate+POEA & 50.0 & 12.5 & $80.06 \pm 24.42$ & 7 \\
\hline
\end{tabular}

study gives additional evidence to support the hypothesis of metabolic arrest associated to glyphosate.

In a more recent study, an inhibition of pyruvate kinase, a key enzyme of the Kreb's cycle, has been reported in $C$. quadricarinatus juveniles exposed during 60 days to 10 $\mathrm{mg} / \mathrm{L}$ of pure glyphosate [25]. The shrimp Palaemonetes pugio also exhibited a decline in oxygen consumption, together with inhibition of several Krebs cycle enzymes, after a chronic exposure to the herbicide pentachlorophenol [26]. It has been also suggested that the surfactant POEA could act synergistically with glyphosate at the mitochondrial level, affecting oxidative phosphorylation [27]. Alternatively, another possible mechanism for the observed decrease in the oxygen consumption may be the inhibition in the $\mathrm{Na}^{+} / \mathrm{K}^{+}$ATPase pump. To this respect, when crayfish were exposed to Roundup the membrane potential of lateral muscle increased, indicating a possible intracellular accumulation of $\mathrm{Na}^{+}$due to a possible inhibition of the $\mathrm{Na}^{+} / \mathrm{K}^{+}$ATPase pump [28].

A significantly $(\mathrm{p}<0.05)$ lower glycogen level was detected in muscle, between either $\mathrm{P}$ or $\mathrm{G}+\mathrm{P}$ and the control, while $G$ group had an intermediate level (Fig. 3). Protein content in muscle was only significant $(\mathrm{p}<0.05)$ reduced in the $\mathrm{P}$ group, with respect to either control or the remaining groups (Fig. 3). Therefore, POEA per se produced a significant decrease both in muscle glycogen and protein concentration. This result suggests that POEA acts as a typical chronic stressor, stimulating the utilization of energetic reserves in order to face a long-term stressful situation. In muscle, POEA caused a decreased in glycogen concentration either alone or in combination with glyphosate, but a reduction of muscle protein was caused by POEA administered alone. Muscle protein commonly begins to be used when the stress becomes more important [29]. Taking also into account that glyphosate, as mentioned above, seems to exert a metabolic arrest to some extent, the combination of POEA and glyphosate would demand a lower energetic cost than POEA alone.

In crustaceans, glycogen has been reported as the primary source of energy [30] and its levels can be affected by stress [31]. Fish have also shown a decrease of muscle glycogen reserves after exposure to glyphosate based herbicides, suggesting that these animals use muscle glycogen as an energy source to compensate for this stress situation [13]. Similar results were obtained in crustaceans exposed to

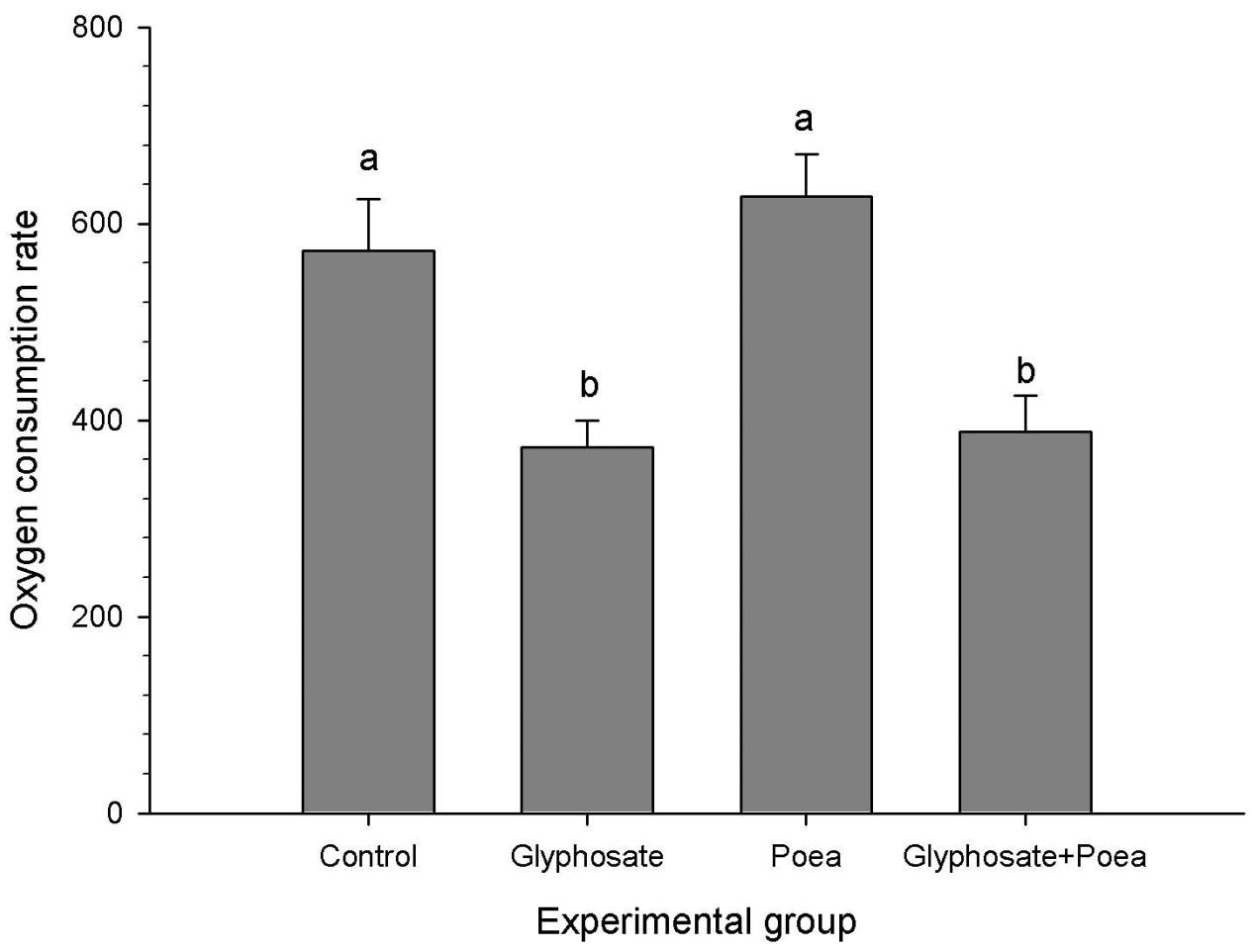

Fig. (1). Oxygen consumption at the end of the experiment. Different letters indicate significant $(\mathrm{p}<0.05)$ differences among groups. 


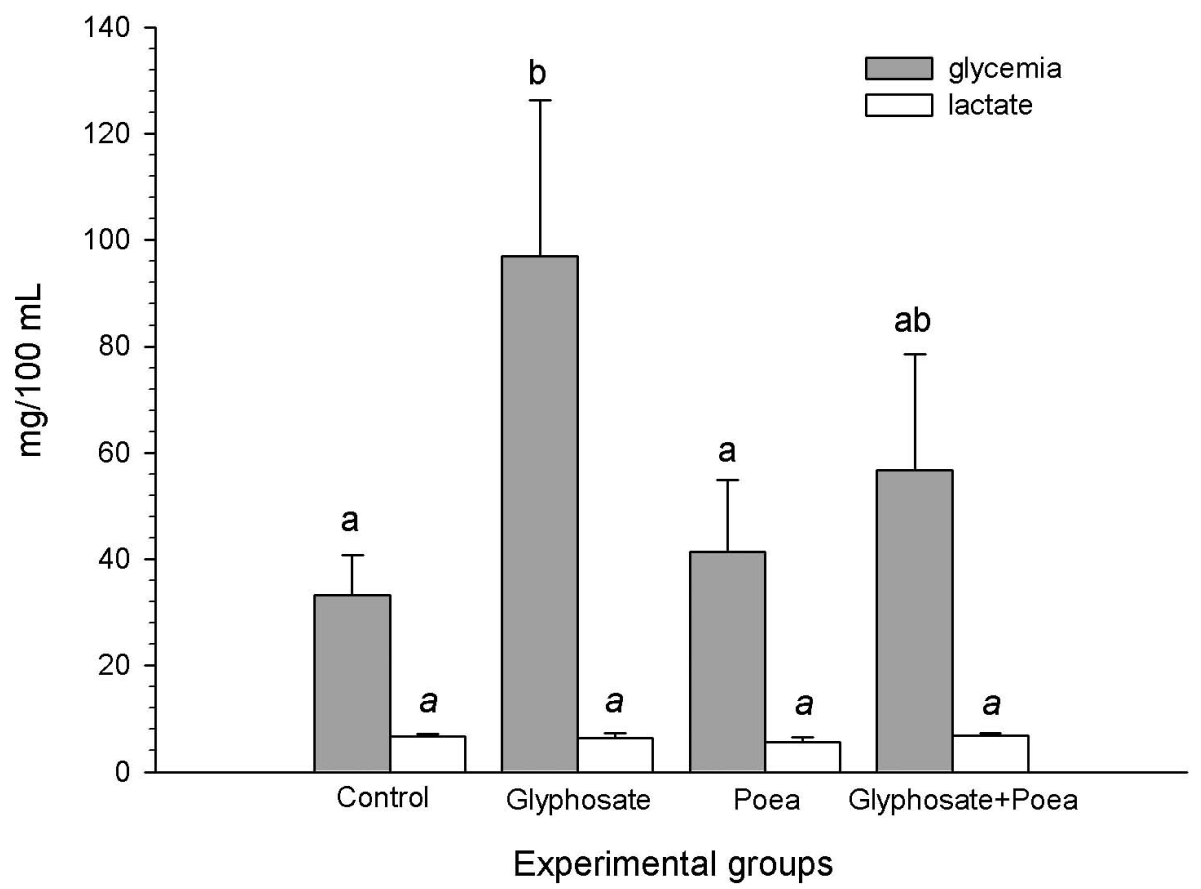

Fig. (2). Hemolymphatic glucose and lactate levels at the end of the experiment. Different letters (same style) indicate significant (p<0.05) differences between groups.

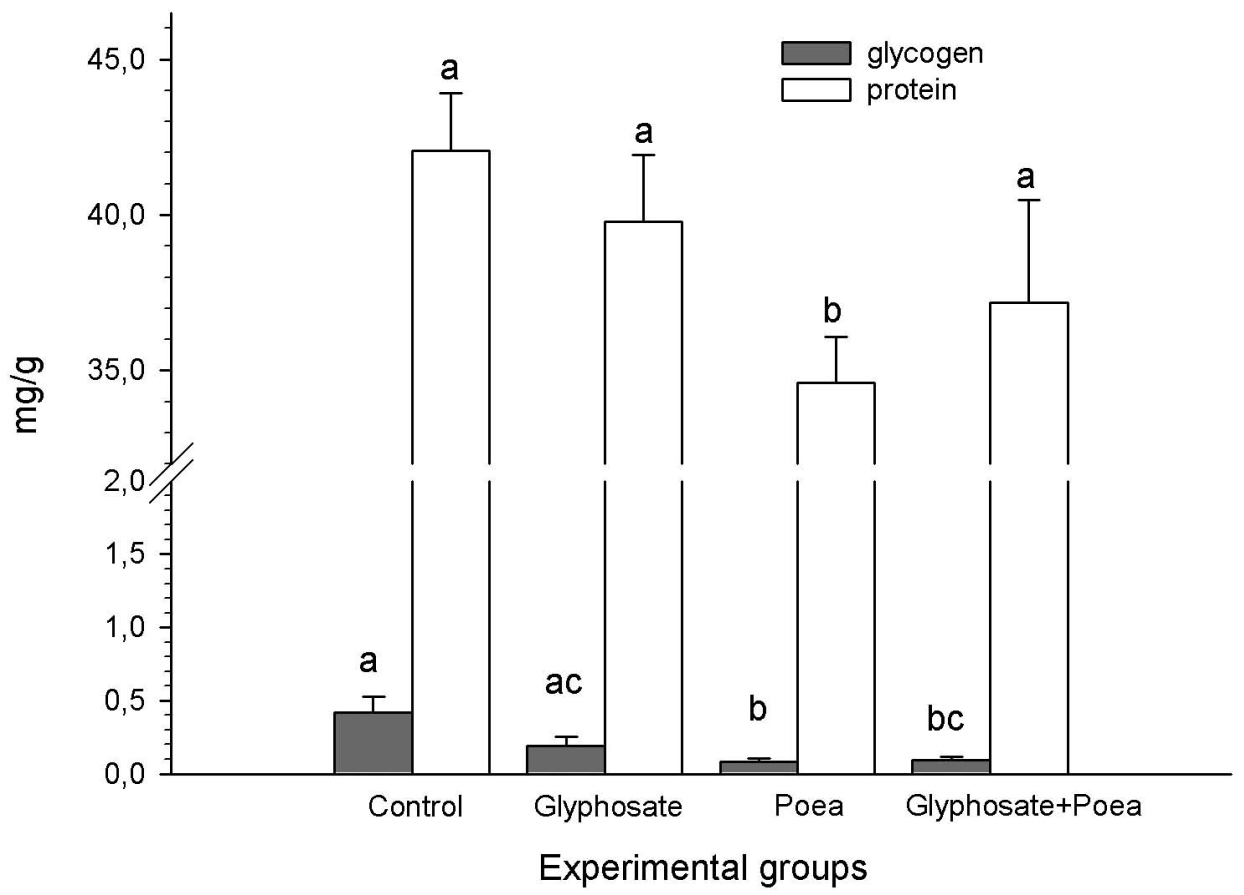

Fig. (3). Glycogen and protein levels in muscle at the end of the assay. Different letters (same style) indicate significant (p<0.05) differences between groups.

various toxicants [32,33]. On the other hand, the crustacean hepatopancreas is able to carry out gluconeogenesis from muscle protein as substrate, to elevate glycemia for supporting a higher metabolic demand [34]. A drop in the level of protein of white muscle has also been reported in freshwater fish exposed to Roundup ${ }^{\circledR}$ [13], suggesting a similar effect.

\section{CONCLUSION}

Our results demonstrate that both, the active ingredient glyphosate and the added surfactant POEA mediate the detrimental effects of exposure to Roundup in the crayfish Procambarus clarkii. Specifically, glyphosate reduces the metabolic rate and increases glycemia with no changes in lactate levels, suggesting a metabolic arrest, while POEA 
reduces both glycogen and protein in muscle, probably acting as an unspecific stressor.

\section{CONFLICT OF INTEREST}

The authors confirm that this article content has no conflict of interest.

\section{ACKNOWLEDGEMENTS}

This study was supported by grants from ANPCYT (PICT2010-0908), UBACYT 2012-2015 (code 044) and PIP CONICET (2010-2012 program, code 100884), as well as by the Widener University.

\section{REFERENCES}

[1] Carlisle SM, Trevors JT. Glyphosate in the environment. Water Air Soil Pollut 1988; 39: 409-20.

[2] Lydon J, Duke SO. Pesticide effects on secondary metabolism of higher plants. Pest Sci 1989; 25: 361-73.

[3] Giesy JP, Dobson S, Solomon, KR. Ecotoxicological risk assessment for Roundup herbicide. Rev Environ Contam Toxicol 2000; 167: 35-120.

[4] National Pesticide Use Database. Washington, DC. CropLife Foundation; [cited January 15, 2007]. Available from: http://www.croplifefoundation.org/

[5] Solomon KR, Thompson DG. Ecological risks assessment for aquatic organisms from over-water uses of glyphosate. J Toxicol Environ Health B 2003; 6: 289-324.

[6] Mann RM, Bidwell JR. The toxicity of glyphosate and several glyphosate formulations to four species of southwestern Australian frogs. Arch Environ Contam Toxicol 1999; 36: 193-9.

[7] World Health Organization. IPCS Environmental Health Criteria 159: Glyphosate, World Health Organization, Geneva 1994; p. 177.

[8] Howe CM, Berrill M, Pauli BD, Helbing CC, Werry K, Veldhoen $\mathrm{N}$. Toxicity of glyphosate-based pesticides to four North American frog species. Environ Toxicol Chem 2004; 23: 1928-38.

[9] Relyea RA. The lethal impact of Roundup on aquatic and terrestrial amphibians. Ecol Appl 2005; 15: 1118-24.

[10] Wagner N, Lötters S. Possible correlation of the worldwide amphibian decline and the increasing use of glyphosate in the agrarian industry, Bundesamt für Naturschutz (BfN), Federal Agency for Nature Conservation 2013; pp. 202.

[11] Szarek J, Siwick A, Andrzejewska A, Terech-Majewska E, Banaszkiewics T. Effects of the herbicide Roundup on the ultrastructural pattern of hepatocytes in carp (Cyprinus carpio). Mar Environ Res 2000; 50: 236-66.

[12] Jiraungkoorskul W, Upatham ES, Kruatrachue M, Sahaphong S, Vichasri-Grams S, Pokethitiyook P. Biochemical and histopathological effects of glyphosate herbicide on Nile tilapia (Oreochromis niloticus). Environ Toxicol 2003; 18: 260-7.

[13] Glusczak L, Miron DS, Moraes BS, et al. Acute effects of glyphosate herbicide on metabolic and enzymatic parameters of silver catfish (Rhamdia quelen). Comp Biochem Physiol 2007; 146C: $519-24$.

[14] Mensah PK, Muller WJ, Palmer CG. Using growth measures in the freshwater shrimp Caridina nilotica as biomarkers of Roundup ${ }^{\circledR}$ pollution of South African freshwater systems. Phys Chem Earth 2012; 50-52: 262-8.

[15] Frontera JL, Vatnick I, Chaulet A, Rodríguez EM. Effects of glyphosate and polyoxyethylenamine on growth and energetic reserves in the freshwater crayfish Cherax quadricarinatus (Decapoda, Parastacidae). Arch Environ Contam Toxicol 2011; 61: $590-8$.
[16] Coupe RH, Barlow JRB, Capel PD. Complexity of human and ecosystem interactions in an agricultural landscape. Environ Dev 2012; 4: 88-104

[17] Chang FC, Simick MF, Capel PD. Occurrence and fate of the herbicide glyphosate and its degradate aminomethylphosphonic acid in the atmosphere. Environ Toxicol Chem 2011; 30: 548-555.

[18] Moore MT, Lizotte Jr RE, Knight SS, Smith Jr S, Cooper CM. Assessment of pesticide contamination in three Mississippi Delta oxbow lakes using Hyalella azteca. Chemosphere 2007; 67: 2184 91.

[19] Reddy PS, Tuberty SR, Fingerman M. Effects of cadmium and mercury on ovarian maturation in the red swamp crayfish, Procambarus clarkii. Ecotoxicol Environ Saf 1997; 37: 62-5.

[20] Naqvi SM, Howell RD. Toxicity of cadmium and lead to juvenile red swamp crayfish. Procambarus clarkii, and effects on fecundity of adults. Bull Environ Contam Toxicol 1993; 51: 303-8.

[21] American Public Health Association, American Water Works Association, Water Pollution Control Federation. Standard Methods for the Examination of Water and Wastewater, 18th ed., American Public Health Association: Washington, DC 2005; p. 1200.

[22] Van Handel E. Estimation of glycogen in small amount soft tissue. Anal Biochem 1965; 11: 256-65.

[23] Lowry OH, Rosenbrough NJ, Randall RJ. Protein measurements with the Folin phenol reagent. J Biol Chem 1951; 183: 265-75.

[24] Sokal RR, Rohlf FJ. Biometry, $2^{\text {nd }}$ ed. Freeman: New York 1981; pp. 832.

[25] Avigliano L, Fassiano AV, Medesani DA, Ríos de Molina MC, Rodríguez EM. Effects of glyphosate on growth rate, metabolic rate and energy reserves of early juvenile crayfish, Cherax quadricarinatus M. Bull Environ Contam Toxicol 2013; 92(6): 631-5.

[26] Ranga Rao K, Fox FR, Conklin AC, Cantelmo AC, Brannon AC. In: Vernberg $\mathrm{W}$, Ed. Physiological and biochemical investigation of the toxicity of pentachlorophenol to crustaceans. Marine Pollution. Functional Responses. Academic Press: New York 1979; 307-39.

[27] Peixoto F. Comparative effects of the Roundup and glyphosate on mitochondrial oxidative phosphorylation. Chemosphere 2005; 61: 1115-22.

[28] Johnson RL, Kizer GM, Loucks JL. Chronic exposure to Roundup ready to use weed and grass killer increases the resting membrane potential of crayfish lateral extensor muscle cells. Pioneering Neurosci 2000; 1: 71-5.

[29] Mayer FL, Versteeg DJ, McKee MJ, Folmar LC. In: Huggett RJ, Kimerle RA, Mehrle PM, Bergman HL, Eds. Physiological and Nonspecific Biomarkers. Biomarkers, Biochemical, Physiological, and Histological Markers of Anthropogenic Stress. Lewis Publishers: Boca Raton 1992; pp. 5-85.

[30] Herreid CF, Full RJ. In: Burggren WW, McMahon BR, Eds. Biology of the land crabs. Cambrige University Press, Cambridge 1988; pp. 333-77.

[31] Chang ES. Stressed-out lobsters: crustacean hyperglycemic hormone and stress proteins. Integr Comp Biol 2005; 45: 43-50.

[32] Coglianese M, Neff JM. In: Vernberg WB, Calabrese A, Thurberg FP, Vernberg EJ, Eds. Biochemical responses of the blue crab, Callinectes sapidus to pentachlorophenol. Physiological mechanisms of marine pollutant toxicity. Academic Press: New York 1982; pp. 127-43.

[33] Graney RL, Giesy JP. Effects of long-term exposure to pentachlorophenol on the free amino acid pool and energy reserves of the freshwater amphipod Gammarus pseudolimnaeus Bousfield (Crustacea, Amphipod). Ecotoxicol Environ Saf 1986; 12: 233-51.

[34] Martins TL, Chittó ALF, Rossetti CL, Brondani CK, Kucharski LC, Da Silva RSM. Effects of hypo- or hyperosmotic stress on lipid synthesis and gluconeogenic activity in tissues of the crab Neohelice granulata. Comp Biochem Physiol 2011; 158A: 400-5. 